BMJ Open Sport \& Exercise Medicine

\section{Athlete medicine applied in a pandemic: disparities among athletes and performers reveal the need for a true 'revolution' in health care}

To cite: Tucker C, Antoniak K, Edison B. Athlete medicine applied in a pandemic: disparities among athletes and performers reveal the need for a true 'revolution' in health care. BMJ Open Sport \& Exercise Medicine 2021;7:e000977. doi:10.1136/ bmjsem-2020-000977
Check for updates

(c) Author(s) (or their employer(s)) 2021. Re-use permitted under CC BY-NC. No commercial re-use. See rights and permissions. Published by BMJ.

${ }^{1}$ Kinesiology and Nutritional Science, Cal State LA, Los Angeles, California, USA ${ }^{2}$ Orthopaedics, Children's Hospital of Los Angeles, Los Angeles, California, USA ${ }^{3}$ USC Keck School of Medicine, Los Angeles, California, USA

Correspondence to Bianca Edison; bedison@chla.usc.edu

\section{ABSTRACT}

While society watches athletes and artists on a screen during the COVID-19 pandemic, some proponents tout 'normalcy' as the moment live in-action play resumes again. However, when we 'see' these athletes, are we truly seeing them? Failing to understand and address athletes' adversity faced during this pandemic amidst social pressures to return to play under a preconceived notion of 'normal' commoditises athletes; instead, we must humanise them while recognising additional burdens they bear amidst unmet healthcare needs. Athletes and performers represent a unique population; they stand at the intersection of racial and socioeconomic health inequity and societal expectations for entertainment. Returning to the field or stage suddenly, unscathed by effects of global viral and racial pandemics, is impossible. Instead, athletes face resuming play with a sobering realisation the pursuit of health is not fulfilled with the same tenacity for everyone. This editorial is to raise awareness to disparities that exist for athletes and performing artist athletes during the COVID-19 pandemic and beyond.

While society watches athletes and artists on screens during the COVID-19 pandemic, some proponents tout 'normalcy' as the moment live in-action play resumes without fully realising or acknowledging the complex struggles athletes are enduring during this time. Failing to understand and address athletes' adversity faced during this pandemic amidst social pressures to return to play under a preconceived notion of 'normal' commoditises those sport performers. ${ }^{1}$ Instead, we must humanise them while recognising additional burdens they bear while facing unmet healthcare needs. We cannot forget to care for our athletes who are carrying our burden of social healing in the aftermath of collective acute or acute on chronic physical and psychological trauma experienced during this time.

Athletes and performers represent a unique population; they stand at the intersection of racial and socioeconomic health inequity and societal expectations for entertainment. Returning to the field or stage suddenly, unscathed by effects of global viral and racial pandemics, is impossible. Sports do not transcend racial socialisation but are alternatively intertwined in systemic practices that contribute to inequities and disparities. Discrimination and segregation within sports persist, a reality clouded behind a veil of race neutrality which produces false racial ideologies that are purported socially and internalised. The fallacy of this illusion of true inclusion in sports becomes apparent for Black and Brown players in sports such as golf, ice hockey, swimming and ballet. ${ }^{2}$ Rather than fully celebrating the return to a social phenomenon or pastime that can help unify and promote positivity, athletes instead face resuming play with a sobering realisation the pursuit of health is not fulfilled with the same tenacity for everyone.

Acknowledging the tremendously challenging feats of athleticism we continuously ask athletes and performers while ensuring proper access to multidisciplinary care teams should be prioritised when considering resuming sport. Failing to concede or address the mental and physical anguish players from underserved communities have experienced is negligent and can fuel distrust of a system that exists on a public platform to nurture and support. The drive to a payto-play sport model highlights inequities that perpetuate racism, commercialisation, ethnocentrism and misguided patriotism that create rifts between communities of players. The COVID-19 pandemic has left underserved and underrepresented athletes vulnerable; mortality and morbidity rates in people of colour are disproportionately higher compared with White populations. ${ }^{3}$ This is not a profound revelation or a new health phenomenon.

For minoritised communities, an unequal system, limited by access to resources and downstream care, focuses on treating symptoms of 
advanced disease rather than prevention. ${ }^{45}$ Preventable conditions overtreated in late stages and undertreated early on lead to higher rates of morbidity and death, ${ }^{6}{ }^{7}$ underscoring institutional racism's profound influence on health. At every level of income and education, race has perpetual effects. Research found Black patients in the Emergency Room significantly less likely than White patients to receive analgesics for extremity fractures $(57 \%$ vs $74 \%$ ), despite having similar pain reports. ${ }^{8}$ Division I Black student athletes are falsely rated by sports medicine providers as having higher pain tolerances than White student athletes for identical injuries, ${ }^{9}$ again perpetuating myths steeped in historically racist ideologies and translating to decreased treatment options for underserved athletes. One's zip code more succinctly predicts health outcomes than genetic makeup, ${ }^{10}$ and financial impacts of the pandemic highlight enduring racial inequalities in society. Black and Brown communities are disproportionately affected during this pandemic and financial crisis, which in turn creates changes in the social structure of communities, access to housing, sports programmes and facilities. Unequal access to resources and healthcare voraciously impacts communities of colour to include underserved athletes and performers at all levels.

Shelter in place orders can be catastrophic for minoritised athletes when their environment is not conducive to thrive. Strictly remaining homebound can stymie the ability to train effectively due to scarce access to proper resources (ie, equipment, space) or needed medical treatments, thus potentially asking an athlete to sacrifice health and/or livelihood. Cancelling events in the absence of additional support to address athletes' mental, emotional, financial and physical well-being fails to acknowledge their ongoing health needs. Research shows that removing one's connection to sport or failing to provide access to necessary resources riddles an athlete and performer with tremendous psychosocial and physical consequences as they navigate difficulties with identity, depression, grief, isolation and hopelessness. ${ }^{410}$

A collaborative approach with an interdisciplinary model as the norm helps provide value-based healthcare and a commitment to advocating for equal access to services within a biopsychosocial framework. To achieve this model for marginalised athletes, we must examine the process of transitioning back to training and performing through multiple lenses, including social, health, safety, emotional and psychological standpoints. Coaches, athletic departments and providers must improve access to multidisciplinary care. This approach can provide appropriate physical and mental health screenings, as well as adjust training loads in response to effects from COVID-19. Educational and athletic institutions must address securing basic logistics (equipment and supplies), enhancing food security and recruiting a diverse taskforce reflective of the communities they serve. The media must acknowledge the role it assumes in communicating race-based messages and ideologies to society. At a policy level, programmes need to create systems that identify the needs and opinions of true stakeholders, namely, the athletes these policies and programmes serve. When addressing inequality, solely relying on those who do not endure disparity to create 'solutions' without consulting, validating and creating space for those directly impacted by social inequity positions programmes for failure before even starting. In addition, accreditation bodies must require antiracism training. Leaders and stakeholders, including coaches, administrators, media and healthcare workers, need to learn how to name racism, identify ways in which systemic bias is currently being perpetuated and institute change so that opportunity and power are more equitably redistributed.

Healthcare is a reflection of social justice, our political system and history. ${ }^{7}$ If unmet healthcare needs, exacerbated by racism and social inequality, and unrealistic social expectations are not met by calls to action with best practices, intertwined with empathy, excellence and tenacity, efforts will be futile. Regardless of one's zip code or background, accreditation bodies, media, administration, fans and care providers need to practice from an understanding of what it means to be underrepresented, underserved, overlooked and undertreated. We need to collectively acknowledge the humanity of our athletes and the health and social disparities they face, highlighted by the COVID-19 pandemic. Now is the time to 'perform' medicine as it truly should be performed.

Correction notice This article has been corrected since it first published. The provenance and peer review statement has been included

Contributors The authors have indicated no potential conflicts of interest to disclose. Contributors' Statements: KA, CT and BE: manuscript writing, manuscript review and submission. All authors approved the final manuscript as submitted and agree to be accountable for all aspects of the work.

Funding The authors have not declared a specific grant for this research from any funding agency in the public, commercial or not-for-profit sectors.

Competing interests None declared.

Patient consent for publication Not required.

Provenance and peer review Not commissioned; externally peer reviewed.

Open access This is an open access article distributed in accordance with the Creative Commons Attribution Non Commercial (CC BY-NC 4.0) license, which permits others to distribute, remix, adapt, build upon this work non-commercially, and license their derivative works on different terms, provided the original work is properly cited, appropriate credit is given, any changes made indicated, and the use is non-commercial. See: http://creativecommons.org/licenses/by-nc/4.0/.

\section{ORCID iD}

Bianca Edison http://orcid.org/0000-0003-3181-5758

\section{REFERENCES}

1 Zirin D, Boykoff J. The Olympics Teeter on the brink, 2020. Available: https://www.thenation.com/article/ world/2020-olympicscoronavirus-cancel/

2 Davis T. The myth of the Superspade: the persistence of racism in college athletics, 22 Fordham URB. L.j 1995;615.

3 The COVID racial data Tracker. The COVID tracking project. Available: https://covidtracking.com/race

4 Sohn H. Racial and ethnic disparities in health insurance coverage: dynamics of gaining and losing coverage over the life-course. Popul Res Policy Rev 2017;36:181-201.

5 Gehlert S, Sohmer D, Sacks T, et al. Targeting health disparities: a model linking upstream determinants to downstream interventions. Health Aff 2008;27:339-49.

6 Institute of Medicine (US) Committee on Understanding and Eliminating Racial and Ethnic Disparities in Health Care; Smedley BD, Stith AY, Nelson AR, editors. Unequal treatment: confronting racial and ethnic disparities in health care. Washington (DC: National Academies Press (US), 2003Paper Contributions. 
7 Anderson JM, Rodney P, Reimer-Kirkham S, et al. Inequities in health and healthcare viewed through the ethical lens of critical social justice: contextual knowledge for the global priorities ahead. ANS Adv Nurs Sci 2009;32:282-94.

8 Todd KH, Deaton C, D'Adamo AP, et al. Ethnicity and analgesic practice. Ann Emerg Med 2000;35:11-16.
9 Druckman JN, Trawalter S, Montes I, et al. Racial bias in sport medical staff's perceptions of others' pain. J Soc Psychol 2018;158:721-9.

10 Williams DR, Collins C. Racial residential segregation: a fundamental cause of racial disparities in health. Public Health Rep 2001;116:pp.:404-16. 